\title{
Polisi Hadir, Negara Hadir
}

\author{
Slamet Pribadi
}

Fakultas Hukum, Universitas Bhayangkara Jakarta Raya

Korespondensi: slametpribadi_99@yahoo.com

\section{Info Artikel}

Naskah diterima : 24 Feb 2020 | Revisi : 2 Mar 2020 | Disetujui : 12 Mar 2020

\begin{abstract}
Abstrak
Polisi sebagai salah satu pelaksana Fungsi Pemerintahan dibidang Harkamtibmas, perlidungan dan Pelayananan kepada Masyarakat, serta Melakukan Penegakan Hukum, senantiasa berada di tengah-tengah masyarakat, untuk melaksanakan tujuan Negara, yaitu melindungi dan melayani masyarakat dari ganguan Kamtibmas. Kehadiran Polisi ditengah-tengah masyarakat adalah sebuah keniscayaan yang harus dilakukan, karena Polisi adalah Pengemban Fungsi kamtibmas, hadir sebagai alat perubahan sosial, mendinamiskan keadaan sosial, agar masyarakat dapat melaksanakan kegiatan sosial dapat berjalan secara aman tanpa ada gangguan.
\end{abstract}

Kata kunci: polisi hadir, negara hadir

\begin{abstract}
The police as one of the executors of the Government Functions in the field of Harkamtibmas, protection and services to the community, as well as conducting law enforcement, are always in the midst of the community, to carry out the State's goal, namely to protect and serve the public from the interference of Kamtibmas. The presence of the police in the midst of the community is a necessity that must be done, because the police are the bearers of the Kamtibmas function, present as a means of social change, to dynamize social conditions, so that people can carry out social activities safely without disturbance.
\end{abstract}

Keywords: police present, state present

\section{PENDAHULUAN}

Polisi adalah Profesi yang sangat mulia, dihadapan Tuhan dan Manusia, dengan jabatan dan kewenangannya bisa merubah, mendinamisir, menstabilkan situasi sosial, juga dapat menjadi mesin pendingin atau cooling system (Meminjam istilah yang sering disampaikan di berbagai kesempatan oleh Mantan Kapolri saat 
itu Jenderal Polisi M Tito Carnavian, yang selalu dikutip oleh berbagai media maupun dalam sambutan beliau ${ }^{1}$ ), pada intinya menjadi alat perubahan sosial, menjadi alat untuk memecahkan persoalan, yang setiap saat memberikan perubahan-perubahan sosial, agar terjadi ketertiban sosial dan harmoni sosial, yang sangat dibutuhkan masyarakat untuk lancarnya interaksi sosial antara yang satu dengan yang lain. Bahkan dengan pangkat apapun yang disandangnya, dalam keadaan apapun atau dalam keadaan tertentu, kekuasaan dan kewenangan yang ada padanya sesuai UU, bisa menentukan nasib seseorang dalam satatus hukum tertentu, dengan tetap menghormati HAM, harus bisa menjadi cooling system.

Pemikiran Jenderal Tito Carvian soal cooling system tersebut sejalan dengan pemikian yang dalam Pemolisian Masyarakat yang mengedepankan Masyarakat sebagai Pemilik Kamtibmas, dimana kejahatan itu lahir, tumbuh dan berkembang di tengah-tengah masyarakat, oleh karenanya Masyarakat harus bersama-sama Kepolisian untuk memelihara stabilitas Kamtibmas yang berkarakter Sipil, karakter yang diharuskan terjadi di dalam Negara Demokratis, dimana supremasi sipil mendapat tempat terhormat sebagai penyangga utama demokrasi. Sehingga Mohammad Tito Karnavian dan Hermawan Sulistyo atas Polisi yang berkarakter sipil ini mengatakan sebagai berikut: Pertama, Polisi Sipil menghormati hak-hak Sipil, masyarakat demokratis membutuhkan Polisi sipil yang mampu berperan sebagai pengawal nilai-nilai sipil. Nilai-nilai ini telah dirumuskan dalam HAM yang dijamin sebagai hukum positip Negara (the guardian of civilian values). Kedua, Polisi Sipil mengedepankan pendekatan kemanusiaan. Karakter sipil secara luas dikaitkan dengan nilai-nilai peradaban (civilization) dan keadaban (civility). Ketiga, fungsi Kepolisian ditujukan untuk menciptakan keamanan dalam negeri, ketertiban dalam masyarakat, pelayanan dan bantuan kepada masyarakat, penegakan hukum dan pemolisian masyarakat (community policing). ${ }^{2}$

Profesi Polisi sangat unik, kekuasaanya bisa dilakukan dengan cara soft power dan pada kondisi tertentu kekuasaan hard power digunakan, dengan cara tegas terukur, tergantung kondisi semacam apa yang harus diambil dengan putusan yang cepat tepat. Profesi seperti Polisi ini tidak dimiliki oleh Profesi lainnya, sangat

\footnotetext{
1 https://jurnalpatrolinews.co.id/berita/read/kapolri-aktifkan-cooling-system-dinginkansituasi-panas-pemilu

2 Muhammad Tito Karnavian, Hermawan Sulistyo, Democrating Policing, Jakarta, Penerbit Pensil324, halaman 139.
} 
unik. Semua yang ada di dalam uniform Polisi, termasuk gerakan tubuhnya, merupakan simbol-simbol kekuasaan dan kewenangan, gerakan kepala, gerakan kaki, gerakan tubuh, pakaian dan simbol-simbolnya, memberikan makna adanya sebuah kekuatan kekuasaan, kewenangan, pelayanan dan Perlidungan kepada masyarakat.

Dengan luasnya kewenangan dan kekuasaan sebagai pemegang jabatan Polisi, maka beberapa aturan diterapkan sangat ketat, baik UU soal Kepolisian, Azas Umum Pemerintahan yang baik, maupun Kode Etik Kepolisian. Bahkan aturanaturan yang bersifat Internasional juga diterapkan kepada Jabatan Polisi, berupa penghormatan terhadap Hak Azasi Manusia yang bersifat Internasional, disamping penghormatan Hak Azasi Manusia yang ada di UU HAM di Indonesia.

Di satu sisi Polisi adalah alat kekuasaan sebuah Pemerintahan, baik yang Demokratis atau yang tidak Demokratis, agar Pemerintahan itu dapat melaksanakan Pemerintahanya, kalau itu pemerintahan yang Demokratis, Polisinya harus tunduk kepada hukum positip yang berlaku, kalau Pemerintahan itu tidak demokratis maka Polisi juga tunduk kepada kekuasaan yang sedang memimpin Negara itu. Sedangkan di Indonesia Polisinya tunduk kepada Pemerintahan, karena salah satu Pelaksana Fungsi Pemerintahan, dan juga tunduk kepada hukum positip, dan Kebijakan Hukum yang berlaku di Indonesia.

Disisi lain, Jabatan Polisi, khususnya yang menyangkut soal Kriminalistik, Polisi terikat dengan berbagai aturan dalam Hukum Materiil dan Hukum Formil, dimana posisi Polisi sebagai salah satu elemen dari Sistem Peradilan Pidana bersama dengan Aparatur lainnya yang bekerja di Sistem Peradilan Pidana, yaitu Kejaksaan dan Pengadilan serta bahkan Lembaga Pemasyarakatan, serta para Penasehat Hukum. Disini Polisi ditempatkan sebagai Penegak Hukum yang harus mengimplementasikan hukum publik, mewakili Negara menegakkan Hukum dan etika sosial, disaat seseorang melakukan pelanggaran kriminal disatu sisi, sementara di sisi lainya ada orang atau sekelompok orang dirugikan, bahkan Negara juga dirugikan.

\section{PEMBAHASAN}

\section{A. Tugas pokok dan Kewenangan Polri}

Kepolisian Negara Republik Indonesia, adalah aparatur Sipil yang dipersenjatai sebagai kesatuan perangkat untuk melaksanankan kewenangannya, 
oleh karenanya tunduk kepada hukum sipil, mempunyai tugas yang sangat berbeda dan sangat berkarakter dari pada aparatur sipil Negara lainnya. Selain diberikan kekuasaan Negara yang diberikan kepadanya juga dilengkapi dengan kewenangan dan dipersenjatai untuk mengimplementasikan kewenangan itu. Tugasnya adalah pemeliharaan keamanan dalam negeri melalui upaya penyelenggaraan fungsi2 kepolisian yang meliputi pemeliharaan keamanan dan ketertiban masyarakat, penegakan hukum, perlindungan, pengayoman, dan pelayanan kepada masyarakat dilakukan oleh Kepolisian Negara Republik Indonesia selaku alat negara yang dibantu oleh masyarakat dengan menjunjung tinggi hak asasi manusia.

Secara khusus menurut Pasal 14 UU no 2 tahun 2002 tentang Kepolisian Negara Republik Indonesia adalah:

1) Dalam melaksanakan tugas pokok sebagaimana dimaksud dalam Pasal 13, Kepolisian Negara Republik Indonesia bertugas:

a. melaksanakan pengaturan, penjagaan, pengawalan, dan patroli terhadap kegiatan masyarakat dan pemerintah sesuai kebutuhan;

b. menyelenggarakan segala kegiatan dalam menjamin keamanan, ketertiban, dan kelancaran lalu lintas di jalan;

c. membina masyarakat untuk meningkatkan partisipasi masyarakat, kesadaran hukum masyarakat serta ketaatan warga masyarakat terhadap hukum dan peraturan perundang-undangan;

d. turut serta dalam pembinaan hukum nasional;

e. memelihara ketertiban dan menjamin keamanan umum;

f. melakukan koordinasi, pengawasan, dan pembinaan teknis terhadap kepolisian khusus, penyidik pegawai negeri sipil, dan bentuk-bentuk pengamanan swakarsa;

g. melakukan penyelidikan dan penyidikan terhadap semua tindak pidana sesuai dengan hukum acara pidana dan peraturan perundangundangan lainnya;

h. menyelenggarakan identifikasi kepolisian, kedokteran kepolisian, laboratorium forensik dan psikologi kepolisian untuk kepentingan tugas kepolisian;

i. melindungi keselamatan jiwa raga, harta benda, masyarakat, dan lingkungan hidup dari gangguan ketertiban dan/atau bencana 
termasuk memberikan bantuan dan pertolongan dengan menjunjung tinggi hak asasi manusia;

j. melayani kepentingan warga masyarakat untuk sementara sebelum ditangani oleh instansi dan/atau pihak yang berwenang;

k. memberikan pelayanan kepada masyarakat sesuai dengan kepentingannya dalam lingkup tugas kepolisian; serta

l. melaksanakan tugas lain sesuai dengan peraturan perundangundangan.

Sedangkan Kewenangan Polri menurut pasal 15 UU no 2 tahun 2002 tentang Kepolisian Negara Republik Indonesia adalah:

1) Dalam rangka menyelenggarakan tugas sebagaimana dimaksud dalam Pasal 13 dan 14 Kepolisian Negara Republik Indonesia secara umum berwenang:

a. menerima laporan dan/atau pengaduan;

b. membantu menyelesaikan perselisihan warga masyarakat yang dapat mengganggu ketertiban umum;

c. mencegah dan menanggulangi tumbuhnya penyakit masyarakat;

d. mengawasi aliran yang dapat menimbulkan perpecahan atau mengancam persatuan dan kesatuan bangsa;

e. mengeluarkan peraturan kepolisian dalam lingkup kewenangan administratif kepolisian;

f. melaksanakan pemeriksaan khusus sebagai bagian dari tindakan kepolisian dalam rangka pencegahan;

g. melakukan tindakan pertama di tempat kejadian;

h. mengambil sidik jari dan identitas lainnya serta memotret seseorang;

i. mencari keterangan dan barang bukti;

j. menyelenggarakan Pusat Informasi Kriminal Nasional;

k. mengeluarkan surat izin dan/atau surat keterangan yang diperlukan dalam rangka pelayanan masyarakat;

l. memberikan bantuan pengamanan dalam sidang dan pelaksanaan putusan pengadilan, kegiatan instansi lain, serta kegiatan masyarakat;

m. menerima dan menyimpan barang temuan untuk sementara waktu.

2) Kepolisian Negara Republik Indonesia sesuai dengan peraturan perundangundangan lainnya berwenang: 
a. memberikan izin dan mengawasi kegiatan keramaian umum dan kegiatan masyarakat lainnya;

b. menyelenggarakan registrasi dan identifikasi kendaraan bermotor;

c. memberikan surat izin mengemudi kendaraan bermotor;

d. menerima pemberitahuan tentang kegiatan politik;

e. memberikan izin dan melakukan pengawasan senjata api, bahan peledak, dan senjata tajam;

f. memberikan izin operasional dan melakukan pengawasan terhadap badan usaha di bidang jasa pengamanan;

g. memberikan petunjuk, mendidik, dan melatih aparat kepolisian khusus dan petugas pengamanan swakarsa dalam bidang teknis kepolisian;

h. melakukan kerja sama dengan kepolisian negara lain dalam menyidik dan memberantas kejahatan internasional;

i. melakukan pengawasan fungsional kepolisian terhadap orang asing yang berada di wilayah Indonesia dengan koordinasi instansi terkait;

j. mewakili pemerintah Republik Indonesia dalam organisasi kepolisian internasional;

k. melaksanakan kewenangan lain yang termasuk dalam lingkup tugas kepolisian.

3) Tata cara pelaksanaan ketentuan sebagaimana dimaksud dalam ayat (2) huruf a dan d diatur lebih lanjut dengan Peraturan Pemerintah.

Sedangkan soal kewenangan lainnya dalam pasal Pasal 16 UU no 2 tahun 2002 tentang Kepolisian Negara Republik Indonesia adalah:

1) Dalam rangka menyelenggarakan tugas sebagaimana dimaksud dalam Pasal 13 dan 14 di bidang proses pidana, Kepolisian Negara Republik Indonesia berwenang untuk:

a. melakukan penangkapan, penahanan, penggeledahan, dan penyitaan;

b. melarang setiap orang meninggalkan atau memasuki tempat kejadian perkara untuk kepentingan penyidikan;

c. membawa dan menghadapkan orang kepada penyidik dalam rangka penyidikan; 
d. menyuruh berhenti orang yang dicurigai dan menanyakan serta memeriksa tanda pengenal diri;

e. melakukan pemeriksaan dan penyitaan surat;

f. memanggil orang untuk didengar dan diperiksa sebagai tersangka atau saksi;

g. mendatangkan orang ahli yang diperlukan dalam hubungannya dengan pemeriksaan perkara;

h. mengadakan penghentian penyidikan;

i. menyerahkan berkas perkara kepada penuntut umum;

j. mengajukan permintaan secara langsung kepada pejabat imigrasi yang berwenang di tempat pemeriksaan imigrasi dalam keadaan mendesak atau mendadak untuk mencegah atau menangkal orang yang disangka melakukan tindak pidana;

k. memberi petunjuk dan bantuan penyidikan kepada penyidik pegawai negeri sipil serta menerima hasil penyidikan penyidik pegawai negeri sipil untuk diserahkan kepada penuntut umum; dan

l. mengadakan tindakan lain menurut hukum yang bertanggung jawab.

2) Tindakan lain sebagaimana dimaksud dalam ayat (1) huruf l adalah tindakan penyelidikan dan penyidikan yang dilaksanakan jika memenuhi syarat sebagai berikut:

a. tidak bertentangan dengan suatu aturan hukum;

b. selaras dengan kewajiban hukum yang mengharuskan tindakan tersebut dilakukan;

c. harus patut, masuk akal, dan termasuk dalam lingkungan jabatannya;

d. pertimbangan yang layak berdasarkan keadaan yang memaksa; dan

e. menghormati hak asasi manusia.

Tugas Pokok, kewenangan dan kekuasaan jabatan anggota Polri sangatlah luas, itu semua semata-mata dipergunakan untuk melindungi Negara dan Penduduk seluruh Indonesia dari gangguan Keamanan dan Ketertiban Masyarakat. Kehadiran Polisi dimanapun merupakan perwujudan kehadiran Negara di tengah-tengah masyarakat. Melindungi dan menjaga Negara, Bangsa, dan Aset Negara.

\section{B. Pelaksana Fungsi Pemerintahan}

Dalam UU no 30 tahun 2014 tentang Administrasi Pemerintahan, dalam pasal 1 butir 2 menyatakan "Fungsi Pemerintahan adalah fungsi dalam 
melaksanakan Administrasi Pemerintahan yang meliputi fungsi pengaturan, pelayanan, pembangunan, pemberdayaan, dan pelindungan"

Polri sebagai salah satu pelaksana fungsi pemerintahan diantara pelaksana fungsi pemerintahan yang lain di jajaran Pemerintahan, Polri senantiasa melaksanakan fungsi pengaturan, fungsi pelayanan, pembangunan, pemberdayaan dan perlidungan masyarakat, baik secara administratip maupun secara aksi lapangan yang langsung berhadapan dengan kepentingan masyarakat, Polri langsung melayani dan melindung masyarakat, agar interaksi sosial sesama anggota masyarakat, antara anggota masyarakat dengan negaranya, dalam pelaksanaan hak dan kewajiban bisa berlangsung dengan baik, sesuai dengan tujuan Negara yang aman dan sejahtera sebagaimana di cita-citakan dalam pembukaan UUD 1945. Meskipun Polri dalam eksistensi Negara hukum telah mempunyai UU tersendiri, yang mengatur secara khusus, disamping UU lain yang berkaitan. Diantaranya adalah Posisi Polri sebagai Penegak Hukum bersama dengan aparat Penegak Hukum lainnya, seperti Kejaksaan, dan Pengadilan dalam satu naungan Sistem Peradilan Pidana.

Seperti yang disebutkan sebelumnya, jabatan Polisi bisa menyentuh kepada hak-hak yang paling dasar seorang manusia, yaitu Hak Azasi Manusia nya, suatu saat hak-hak tersebut bisa dibatasi untuk kepentingan tertentu, terutama melaksanakan perintah Undang-Undang. Pengurangan itu hanya parsial, keadaan tertentu, tidak seluruhnya, dan tentu demi kepentingan hukum. Untuk mengimplementasikan fungsi-fungsi Pemerintahan Negara dibidang tertentu, diperlukan aparatur yang bisa menggerakkan elemen-elemen hukum yang mengatur soal sesuatu itu boleh dilakukan atau tidak boleh dilakukan, serta diberikan sangsi bagi pelanggarnya. Polisi dalam hal ini termasuk sebagai salah satu aparatur Negara, alat kekuasaan pemerintahan, alat Negara, yang melaksanakan fungsi pemerintahan. Jika kemudian di masyarakat ada kebebasan, namun kemudian kebebasan itu bisa dihentikan atas nama UU dan Jabatan Kepolisian, dan atas nama kepentingan Publik, manakala kebebasan itu memberikan dampak yang merugikan orang lain dan Negara.

Sungguh besar kewenangan Polisi itu, bisa mengimplementasikan Hukum sebagai kekuatan yang memaksa, sebagai bagian dari Aparatur Negara secara umum atau Aparatur Hukum secara khusus, ketika tatanan sosial tidak ditaati oleh individu Warga Negara atau sekelompok orang, yang mengakibatkan tatanan sosial itu menjadi tidak beraturan atau tidak tertib atau terjadi kerusakan secara sosial, 
manakala dibiarkan, eskalasinya menjadi meningkat, dan terjadi kerusakan besar atau terjadi kejahatan di tengah-tengah tatanan sosial. Peran Polis disini berdasarkan UU yang mengaturnya, dilaksanakan secara tegas dan terukur.

Dalam pasal 2 UU no 2 tahun 2002 tentang Kepolisian Negara Republik Indonesia mengatur "Fungsi kepolisian adalah salah satu fungsi pemerintahan negara di bidang pemeliharaan keamanan dan ketertiban masyarakat, penegakan hukum, perlindungan, pengayoman, dan pelayanan kepada masyarakat". Dari ketentuan diatas Polri melaksanakan salah satu Fungsi Pemerintahan, yaitu Pemeliharaan kamtibmas, penegakan hukum, perlindunan penayoman dan pelayanan masyarakat. Fungsi pemerintahan disini, melaksanakan Fungsi Pengaturan, Fungsi Pengawasan dan Fungsi Pelayanan. Fungsi Kepolisian tersebut adalah untuk mewujudkan Keamanan Dalam negeri sebagaimana diatur dalam pasal 4 UU no 2 tahun 2002 tentang Kepolisian Negara Republik Indonesia, yaitu: "Kepolisian Negara Republik Indonesia bertujuan untuk mewujudkan keamanan dalam negeri yang meliputi terpeliharanya keamanan dan ketertiban masyarakat, tertib dan tegaknya hukum, terselenggaranya perlindungan, pengayoman, dan pelayanan kepada masyarakat, serta terbinanya ketenteraman masyarakat dengan menjunjung tinggi hak asasi manusia".

Fungsi Pemerintahan dibidang Pemerliharaan Kamtibmas, adalah tugas dan tanggung jawab Kepolisian terhadap terciptanya situasi aman dan tertib di masyarakat, sehingga masyarakat dapat melaksanakan kegiatannya sehari-hari secara nyaman. Tentunya di dalam melaksanakan tugas ini Polri tidak bisa sendirian mengembangkan kebijakannya, harus bekerja sama dengan instansi lain yang terkait. Karena Polri tidak bisa mengelola sendirian, karena faktor lain ikut mendukung situasi. Misalnya membentuk pola keamanan perkotaan di suatu kawasan, harus bekerja sama dengan dinas tata kota, dinas pertanahan, dinas lingkungan hidup, dinas perhubugan dan lain-lain.

Fungsi Pemerintahan dibidang Penegakan Hukum, Polri melaksanakan sebuah proses hukum bersama dengan instansi lain yang terlibat dalam sistem peradilan pidana, yaitu Kejaksaan dan Pengadilan. Polri mendapat amanah dari Negara untuk mengimplementasikan hukum Pidana sebagai hukum publik, untuk memproses seseorang yang telah melangar hukum, merusak tatanan masyarakat yang sudah diatur dalam UU atau melakukan kejahatan sehingga seseorang yang melanggar itu harus mendapatkan hukuman setimpal dengan perbuatannya, 
berupa hukuman badan atau hukuman denda, atau hukuman sosial lainnya berdasarkan perintah UU dan atau perintah Pengadilan. Kebijakan hukum oleh Polri, harus ditopang oleh kebijakan hukum aparatur lain secara bersamaan dalam satu mekanisme yang disepakati, baik soal hukum materiil maupun hukum formil. Bahkan kebijakan umum disektor lain di Negara ini, harus selaras dengan kebijakan hukum yang diemban Polri, dan aparatur hukum lainnya. Pengaruhnya sangat besar jika kebijakan umum tidak dikelola dengan baik, meski kebijakan umum itu bukan otoritas Polri. Pengaruhnya adalah terjadinya gangguan ketertiban dan Kamtibmas, secara umum maupun secara khusus. Penegakan hukum ini oleh Polri ditempatkan pada upaya paling terakhir (ultimum remidium), setelah upaya lain tidak mampu lagi mengatasi, dan dilaksanakan dengan penuh kehati hatian (azas subsidiaritas).

Fungsi Perlindungan Pengayoman dan Pelayanan Masyarakat, fungsi ini adalah Fungsi tugas Umum Kepolisian, baik secara tehnis maupun administratip, meliputi tugas perlindungan dan pelayanan publik, agar masyarakat dapat hidup suasana yang tertib dan aman. Fungsi ini sifatnya preentip dan preventip. Tugas ini dituangkan dalam pasal 14 UU no 2 tahun 2002 tentang Kepolisian Negara Republik Indonesia, adalah sebagai berikut:

1) Dalam melaksanakan tugas pokok sebagaimana dimaksud dalam Pasal 13, Kepolisian Negara Republik Indonesia bertugas:

a. melaksanakan pengaturan, penjagaan, pengawalan, dan patroli terhadap kegiatan masyarakat dan pemerintah sesuai kebutuhan;

b. menyelenggarakan segala kegiatan dalam menjamin keamanan, ketertiban, dan kelancaran lalu lintas di jalan;

c. membina masyarakat untuk meningkatkan partisipasi masyarakat, kesadaran hukum masyarakat serta ketaatan warga masyarakat terhadap hukum dan peraturan perundang-undangan;

d. turut serta dalam pembinaan hukum nasional;

e. memelihara ketertiban dan menjamin keamanan umum;

f. melakukan koordinasi, pengawasan, dan pembinaan teknis terhadap kepolisian khusus, penyidik pegawai negeri sipil, dan bentuk-bentuk pengamanan swakarsa;

g. melakukan penyelidikan dan penyidikan terhadap semua tindak pidana sesuai dengan hukum acara pidana dan peraturan perundangundangan lainnya; 
h. menyelenggarakan identifikasi kepolisian, kedokteran kepolisian, laboratorium forensik dan psikologi kepolisian untuk kepentingan tugas kepolisian;

i. melindungi keselamatan jiwa raga, harta benda, masyarakat, dan lingkungan hidup dari gangguan ketertiban dan/atau bencana termasuk memberikan bantuan dan pertolongan dengan menjunjung tinggi hak asasi manusia;

j. melayani kepentingan warga masyarakat untuk sementara sebelum ditangani oleh instansi dan/atau pihak yang berwenang;

k. memberikan pelayanan kepada masyarakat sesuai dengan kepentingannya dalam lingkup tugas kepolisian; serta

l. melaksanakan tugas lain sesuai dengan peraturan perundangundangan.

2) Tata cara pelaksanaan ketentuan sebagaimana dimaksud dalam ayat (1) huruf f diatur lebih lanjut dengan Peraturan Pemerintah.

Tugas umum diatas lingkupnya adalah soal jiwa dan harta benda serta tertib sosial di lingkungan masyarakat. Pada akhirnya Polisi harus dapat memberikan jaminan keamanan bagi msyarakat secara maksimal dan disini Polisi merupakan kekuatan fungsi Pemerintahanan untuk melaksanakan tujuan keamanan, dimana keamanan adalah salah satu kebutuhan masyarakat yang sangat penting. Ketika keamanan terjamin, tugas umum Kepolisian berjalan lancar, maka masyarakat menerima manfaatnya Kehadiran Polisi dilingkungannya.

Tugas Polisi secara hakiki sangat luas, mengawasi manusia di saat bangun dari tidurnya, beraktivitas, sampai dengan dia tidur kembali, diantara kehidupan itu banyak hal yang dilakukan masyarakat, Polisi memastikan keamanan disaat berlangsunganya aktifitas kehidupan itu. Misalnya mendamaikan pertengkaran keluarga, membantu binatang piaraan yang hilang, ikut bersama merencanakan siskamling, menjaga pilihan lurah untuk memastikan situasi tetap kondusive, ikut serta kerja bhakti desa, patroli blok perumahan sampai urusan pengadilan pidana, ikut serta dalam perdamaian dunia dengan mengirimkan Polisi perdamaian untuk menjaga perdamaian, dan lain sebagainya. 


\section{Kehadiran Polisi}

Polri adalah salah satu aparatur Negara, sebagai alat kelengkapan Negara, diberikan tanggung jawab, kekuasaan dan kewenangan, serta dilengkapi dengan kelengkapan sebagai aparatur Negara, agar kekuasaan dan kewenanganya bisa dilaksanakan dengan baik. Kehadiran Polri dimana saja, kapanpun jua, dalam keadaan apapun, terhadap siapapun, sesuai kewenangannya dalam hukum positip diseluruh Indonesia, harus dapat memastikan bahwa hukum ditaati dengan sebaikbaiknya oleh setiap warga nerara. Hans Kelsen ahli hukum dan Filsuf dari Austria yang lahir tahu 1881 di Praha Ceko mengatakan "Berjalanya Peraturan Hukum secara efektive hanya berarti bahwa orang-orang melakukan perbuatannya sesuai dengan peraturan hukum sesuai dengan peraturan hukum tersebut "3. Lalu dengan kewenangan dan kekuasaan yang begitu tinggi, memberikan harapan yang tinggi pula kepada Kepolisian, masyarakat melihat bahwa suksesnya tugas Kepolisian juga harus ditunjang juga oleh tugas institusi lain yang terintegritas.

Prof Satjipto Raharjo, menampaikan: Diantara pekerjaan-pekerjaan penegak hukum. Pekerjaan Polisi adalah yang paling menarik. Hal tersebut mejadi menarik, karena di dalamnya banyak dijumpai keterlibatan manusia sebagai pengambil keputusan. Polisi pada hakekatnya dapat dilihat sebagai hukum yang hidup, karena ditangan Polisi tersebut hukum mengalami perwujudanya, setidak tidaknya dibidang hukum pidana. Apabila hukum bertujuan untukmenciptakan ketertiban dalam masyarakat, diantaranya denanmelawan kejahatan. Akhirnya Polisi yang akan menentukan secara konkrit apa yang disebutsebagai penegak ketertiban. Siapa-siapa yang harus ditundukkan, siapa-siapa yang harus dilindungi dan seterusnya. Melalui Polisi hal-hal yang bersifat falsafati dalam hukum dapat ditransformasi menjadi ragawi dan manusiawi. Oleh karena sifat pekerjaanya tersebut, Polisi banyak berhubungan dengan masyarakat dan menanggng resiko mendapatkan sorotan yang tajam dari masyarakat. 4

Dikala dianggap bisa menyelesaikan semua masalah tersebut, sebenarnya mitos atau nyata? Memerlukan sebuah jawaban, ternyata jawabanya sangat subyektip, bisa bergantung kepada situasi dan persepsi. Di satu sisi bisa dianggap

\footnotetext{
${ }^{3}$ Hans Kelsen, Teori Umum tentang HUKUM dan NEGARA, diterjemahkan dari buku Hans Kelsen, General Theory of Law and Stater (New York: Rusel and Rusel, 1971), Penerjemah Raisul Muttaqien, Cetakan ke IV, Bandung, Penerbit Nusa Media, halaman 31

${ }^{4}$ SatjiptoRaharjo, PENEGAKAN HUKUM, Suatu Tinjauan Sosiologis, Yogjakarta, Genta Publishing, 2009, cetakan pertama, halaman 111.
} 
sebagai mitos, manakala suatu saat tugas Polisi dianggap tidak berhasil atau bahkan menjadi trauma masyarakat terhadap Polisi, dianggapnya Polisi tidak mampu melindungi masyarakat, namun disisi lain bisa dianggap sebagai kenyataan, bahkan Polisi sebagai dewa penyelamat ketika tugas Polisi berhasil melindungi dan menyelesaikan persoalan yang sangat dinamis dalam masyarakat secara baik.

Suatu saat di suatu ruas jalan tertentu terjadi kemacetan lalu Lintas, karena ada mobil mogok dipinggir jalan, akibatnya terjadi kemacetan panjang, dimana sebenarnya ruas jalan itu setiap hari sudah macet, ditambah dengan adanya mobil yang mogok, maka situasi semakin macet parah. Lalu beberapa pengguna jalan berteriak "mana polisi...?". Ini symbol keinginan masyarakat yang sejujurnya membutuhkan kehadiran Polisi untuk mengurai kemacetan.

Ditempat lain, suatu saat terjadi perkelahian antara kelompok, masingmasing kelompok yang akan bekelahi tersebut jumlahnya cukup banyak, mereka membawa senjata tajam, batu-batu besar, rantai sepeda motor, anak panah beserta busurnya, dan lain-lain senjata. Terjadilah kericuhan, kekacauan, pengrusakan berbagai fasilitas umum. Penduduk sekitar ketakutan berlarian, terutama ibu-ibu dan anak-anak. Beberapa pria teriak “Segera telepon pak kapolsek! Segera! Segera!” salah satu orang berhasil menghubungi Kapolsek "halo Pak Kapolsek.....ada perkelahian pak....anak kampung sebelah dengan anak-anak kampung kita....mohon segera polisi meluncur pak di jalan....... Sekarang pak....sekarang pak....sudah ada yang terluka.....terimakasih pak.....kita tunggu"

Ilustrasi diatas barulah secuil peristiwa, masih banyak peristiwa-peristiwa lain diseluruh Indonesia, baik pada waktu yang sama maupun waktu yang berbeda, yang membutuhkan kehadiran Polisi, untuk menyelesaikan persoalan, menindak pengganggu keamanan dan ketertiban masyarakat, penganggu keserasian sosial. Polisi ditempatkan sebagai sebuah lembaga yang bisa menyelesaikan segala hal. Disimbulkan sebagai kekuatan superhero, di dunia kartun dan film-film, yang serba biasa, dan penyelesaiannya cepat dan instant. Ini bukalah sesuatu yang mustahil, harapan masyarakat sangat besar kepada Polisi. Begitulah gambaran harapan masyarakat kepada Polisi, oleh karenanya selalu mengharap kesempurnaannya, dan mampu menjadi super hero seperti dalam cerita-cerita fiksi.

Dalam sistem hukum Publik, Polisi mendapat tugas dari Negara melalui undang-undangnya untuk menyelesaikan masalah masyarakat. Polisi mewakii Negara, Polisi simbol dari kehadiran Negara dalam kondisi aktip, yang telah 
melaksanakan fungsinya untuk memelihara kamtimas, melindungi, mengayomi dan melayani masyarakat, serta melakukan penegakan hukum. Misalnya, Petugas Reserse yang sedang mengetik untuk membuat Berita acara Pemeriksaan, Petugas Reserse yang menangkap preman di pertokoan, anggota Polantas atau anggota Sabhara yang sedang menggerakkan tangan dan tubuhnya mengatur lalu lintas jalan, anggota Polwan Sabhara yang sedang meniup pluit, mengatur kepadatan jalan di pasar, petugas Patroli Jalan Raya menolong ibu yang melahirkan di Pos Polisi. Kehadiran Negara disimbolkan sebagai kehadiran Polisi dalam keadaan aktip, membantu masyarakat, mendinginkan suasana, memperlancar lalu lintas, menangkap penjahat, dll. Maka ketika Polisi tidak berada ditempat disaat dibutuhkan, bisa dipersepsikan Negara tidak hadir melaksanakan fungsinya. Umpatan lahir dari berbagai kalangan, "dimana Polisi”, "Polisi pada kemana ini" umpatan negatip bisa saja keluar, sebagai tanda kekesalan, sementara sang Polisi istirahat sejenak, ke toilet, sholat, atau menyeruput kopi atau bisa juga sedang melaporkan situasi kepada Pusat Pengendali Operasi di dalam pos penjagaan, hanya berlangsung beberapa menit, pada titik yang sdg dibutuhkan sekali oleh masyarakat.

Keberadaan Anggota Polri ditengah-tengah dinamika sosial Masyarakat haruslah memberikan manfaat, memecahkan persoalan yang rumit di masyarakat, memastikan hukum dan ketertiban sosial dihormati, meskipun terkadang persoalan itu diluar kewenangan Polisi. Juga harus bisa menjadi mesin pendingin/cooling system (Istilah Jenderal Polisi Tito Carnavian/Kapolri), ketika terjadi ada kepentingan politik yang tinggi bahkan bisa memanaskan situasi sosial, disaat pilkada serentak, Pilleg maupun Pilpres, Polisi dituntut untuk mendinginkan situasi, dengan berbagai cara sesuai dengan kewenanganya, baik preemtip, preventive, maupun represive. Tidak heran Polisi bisa dipersepsikan kriminalisasi terhadap kelompok tertentu, Polisi tidak Netral, dan sebagainya. Padahal kebijakan Polisi diawali dari fakta yang tersedia dalam peristiwanya, sesuai kewenangan yang diperintahkan UU.

Kehadiran Polisi adalah sebuah tuntutan sosial dan tuntutan hukum, dimana Polisi berdiri dan bertindak mewakili Negara dalam kondisi aktip dan mewakili Institusi Kepolisian, untuk menyelesaikan persoalan, menyelesaikan konflik. Disadari atau tidak, perfoma Polisi diberbagai tempat dan berbagai kesempatan adalah symbol kehadiran Negara, oleh karenanya penyimpangan yang dilakukan 
Polisi bisa dipersepsikan Negara tidak hadir dikala masyarakat sedang menderita kesusahan.

Kehadiran Polisi adalah sebuah mimpi besar masyarakat, harapan besar masyarakat, dan itu wajar dalam sebuah Negara berdaulat, dimana posisi Polisi ditempatkan sebagai aparatur Negara, Pelaksana salah satu Fungsi Pemerintahan dibidang Harkamtibmas, lin yan yom mas, dan gakkum. Dimanapun Negara diseluruh dunia, termasuk Indonesia, di aparatur lain tidak ada kekuasaan atau kewenangan seperti Polisi, dia aparatur sipil yang dipersenjatai, dilengkapi dengan kewenangan yang sangat luas oleh UUnya, dilengkapi sarana dan prasarana untuk melengkapai kewenangannya itu. Pantas dan layak kemudian Masyarakat mendambakan kehadiran Polisi kapanpun dan dimana pun.

\section{PENUTUP}

\section{A. Simpulan}

Dalam masyarakat demokratis yang modern, Polisi memikul tangung jawab utama, untuk menjamin keamanan masyarakat karena penegakhukum dipandang solusi keluar utama dari kejahatan. ${ }^{5}$ Tugas Polri mempunyai karakter tersendiri, sebagai salah satu pengembang Pelaksana Fungsi Pemerintahan, Polri dalam sistem pemerintahan di Indonesia adalah aparat sipil, namun diberikan senjata dengan jenis dan ukuran tertentu, berbeda jenis dan ukuran dengan rekannya di TNI. Diberikan senjata mengingat tugasnya yang harus memberikan perlindungan kepada Masyarakat, untuk meningkatkan kekuasaan Kepolisian agar tujuan Negara bisa ditegakkan sebagaimana hukum yang diberlakukan. Polisi diberikan kewenangan khusus yang sangat luas untuk melaksanakan tugas dan fungsinya dalam melindungi masyarakat dari gangguan Kamtibmas.

Polisi harus semaksimal mungkin menjadi alat perubahan sosial, dengan kewenangan yang diberikan UU kepada Polisi, bisa melakukan pencegahan terjadikan gangguan kamtibmas, serta melakukan penegak hukum bagi pihak yang melangar hukum.

Kehadiran Polri harus benar-benar memberikan dampak positip bagi masyarakat, karena Polri dibayar dan diberikan kewenangan untuk itu. Kemudian

\footnotetext{
${ }^{5}$ DAVID H. BAYLEY, Police For The Future, Oxford University Press Inc. 198 Madison Avenue, New York. terbitan pertama, 1994. Penyadur Jend Pol (Purn) Kunarto dan Ny. Khobibah M Arif Dimyati, Polisi Masa Depan, Jakarta, Cipta Manunggal, hlm. 241.
} 
di dalam melaksanakan tugasnya berkolaborasi bersama pelaksana fungsi pemerintahan yang lain.

Kehadiran Polisi sebagai simbol hadirnya Negara dalam melaksanakan tujuan Negara, yaitu melindungi masyarakat dari gangguan keamanan dan ketertiban masyarakat, termasuk di Negara yang modern dan demokratis.

\section{DAFTAR PUSTAKA}

Alvin S. Jonson, Sosiologi Hukum, diterjemahkan oleh Rinaldi Simamora, cetakan ketiga, Jakarta: PT Rineka Cipta, Januari 2006.

Bryan A. Garnerm Editor In Chief, Black's Law Dictionary, 1990 West Publishing Co.

David H. Bayley, Police For Future, Penyadur Jenderal (Purn) Kunarto, Ny. Khobibah M Arief Dimyati, Jakarta: PT Cipta Manunggal, 1998.

Hans Kelsen, Teori Umum tentang HUKUM dan NEGARA, diterjemahkan dari buku Hans Kelsen, General Theory of Law and Stater (New York: Rusel and Rusel, 1971), Penerjemah Raisul Muttaqien, Cetakan ke IV, Bandung, Penerbit Nusa Media.

Harsya W. Bachtiar, Ilmu Kepolisian, di cetak oleh PT Gramedia, Jakarta, Penerbit PT Grasindo, 1994.

Hotma P Sibuea, Azas Negara Hukum, Peraturan Kebijakan \& Azas-Azas Umum Pemerintahan yang Baik, Penerbit Erlangga, 2010.

Peter Mahmud Marzuki, Pengantar Ilmu Hukum, Edisi Pertama, Jakarta, Penerbit: Kencana Prenada Media Grup, 2008.

Satjipto Rahardjo, PENEGAKAN HUKUM, Suatu Tinjauan Sosiologis, Yogjakarta, Genta Publishing, 2009, cetakan pertama.

Satjipto Rahardjo, Teori Hukum, Strategi Tertib Manusia Lintas Ruang dan Generasi, Genta Publishing, Yogjakarta, 2010.

Soerjono Soekanto, Sosiologi Suatu Pengantar, Cetakan ketigabelas, Jakarta, Penerbit: CV Rajawali, 1990.

Stephen Schafer, The Political Criminal, New York, A Division of Macmilan Publishing Co, Inc, 1974.

Sutrisno, Sosiologi Kepolisian, Relasi Kuasa Polisi dengan Organisasi Masyarakat Sipil Pasca Orde Baru, Yayasan Pustaka Obor Indonesia, Jakarta, 2016.

Undang-Undang no 30 tahun 2014, tentang Administrasi Pemerintahan

Undang-Undang no 2 tahun 2002 tentang Kepolisian Negara Republik Indonesia 